\title{
Does the first to reach the market always win?
}

First movers

typically achieve

an upper hand

by displaying

technological

leadership and

by preempting

scarce assets.
The first with the most wins. The need to be first is burned into our collective business psyche. The first with a novel service, product, or promotion usually takes the lumps but may seize opportunities to siphon off premiums or lock up the choice customers. Exarnples abound in which "first-mover" or "pioneering" advantages accrued to the earliest innovators. First-mover strategies contributed in large part to achievements like Wrigley's (Chicago, IL) chewing gum, AT\& T's (New York) long-distance service, and Pioneer Hi-Bred's(Des Moines, IA) hybrid seed corn. The onslot of current agbiotech novelties-like Monsanto's (St. Louis, MO) Roundup Ready soybeans, Calgene's (Davis, CA) Flavr Savr tomato, and several firms' advanced, turf-type, Buffalo grasses-may force many to reconsider the potential benefits and risks such companies have undertaken to become first movers. Is there a way to understand the important and delicate nuances of a first mover's strategy?

Marvin Lieberman and David Montgomery first categorized the successes of many first movers and described several unifying features. ${ }^{1}$ First movers typically achieve an upper hand by displaying technological leadership, by preempting scarce assets, or by developing switching costs. Such superiority is balanced against free-rider effects and incumbent inertia. While these techniques may appear obvious, their use by first movers are subtle and refined.

Most naturally conclude that technological leadership must arise from a continual stream of patents or from the patient accumulation of know how. For instance, Monsanto's position in Round-up, coupled with Asgrow's (Kalamazoo, MI) or Pioneer's soybean-breeding acumen, may be an unbeatable combination. However, Lieberman and Montgomery contend that a more subtle advantage exploited by prevailing first movers is production know-how. Learning occurs during production, as the cumulative volume of product manufactured increases. First movers get a substantial head start, as they learn how to make their products more efficiently, so long as their wisdom can be kept secret. By example, the notorious difficulties of packing and shipping Flavr Savr tomatoes, while now a costly irritant for Calgene, may ultimately provide a sizable first-mover advantage that dwarfs Calgene's prowess in genetic engineering.

Controlling scarce assets is another first mover's advantage. On the surface, denying competitors handsome distribution sites, natural resources, or manpower appears attractive. But even the richest first movers can monopolize only a few such choice assets. More frequently, successful first movers employ two discriminating methods. First, they preempt competitors' investment in fixed assets. The first mover usually controls the option to build a plant or production base big enough to supply the entire market. The sizable sunk costs of facilities signal competitors that the first mover is prepared to dominate. The competitors stand warned. Excessive capacity in the industry potentially depresses prices, making the market unprofitable for all. And, second, first movers focus to preempt the mental space that customers use to compare products. This space is called "mind share" by marketing guru Philip Kotler of the J.L. Kellogg Graduate School of Management at Northwestern University (Evanston, IL). The first products to market may define in customers' minds what products in this category are suppose to be like. Coca-Cola, Jell-O, and Kleenex, for instance, are standard bearers to which other brands are compared. Closer to home, Calgene's attempt to build the link between year-round, tasty tomatoes and Flavr Savr is a crucial one in its first-mover strategy.

Switching costs discourage customers from defecting from a first mover's offerings. Actual costs in new software and training are incurred, for example, when a company changes computer systems. Building real switching costs into products is ideal, though usually difficult. Instead, flourishing first movers go after the uncertainty that cus- tomers face as they contemplate switching away from the first movers' proven product. This "fear of loss" by customers actually cements the bond with the first mover, even if the evidence is compelling that a change to a competitive product is beneficial. As an example, the switching costs of abandoning Round-upReady soybeans, once they are integrated into a farmer's production system, could be enormous.

A good first mover plans defensive, as well as offensive, strategies. The first mover must shortcircuit free riders. Free riders are those who enter after the first mover and have waited until the market is better developed, until technological issues have been solved, or until the customers are educated about the product or service. Later entrants may also be in a better position to perceive shifts in technology or customers' needs. Still, later entrants must dislodge the first mover. Finally, while first movers start as innovators, some may suffer from incumbent's inertia. This is the tendency to continue marketing the same innovation to the same customers in the same way, even after the market has changed. It's impossible to predict if Monsanto, Calgene, or other future first movers in plant genetics could fall prey to this malady. A well-studied example of incumbent's inertia was General Motors' (Detroit, MI) 15-year sleep, while the Japanese dominated the supply of economical cars.

Indeed, the preferred strategies of first movers are not typically obvious or blatant. By capturing production experiences, through carefulproduction planning, and with creative marketing, you, too, may aspire to become a first mover. III

1. Lieberman, M.B., and D.B.

Montgomery. 1988. First-mover

advantages. Strategic Management Journal 9:41-58.

George Kidd is president of management consultants Kidd \& Company (Shorewood, WI). (C) George Kidd.

James Dvorak is an associate of Kidd \& Company. 